\title{
Evaluation of Anti-Bacterial Activity of Mansoa alliaceae Leaves
}

\author{
Veenam Bhavya Naga Vani ${ }^{1 *}$, Nayudu Teja ${ }^{2}$ and Tera Sandhya ${ }^{3}$ \\ ${ }^{1}$ Department of Pharmaceutical Analysis, V.V Institute of Pharmaceutical \\ Sciences, Gudlavalleru, Andhra Pradesh, India \\ ${ }^{2}$ Department of Pharmaceutics, V.V Institute of Pharmaceutical Sciences, \\ Gudlavalleru, Andhra Pradesh, India \\ ${ }^{3}$ Department of Pharmacology, Institute of Pharmaceutical Technology, Sri \\ Padmavathi Mahila Viswavidyalayam, Tirupathi, India
}

*Corresponding Author: Veenam Bhavya Naga Vani, Department of Pharmaceutical

Analysis, V.V Institute of Pharmaceutical Sciences, Gudlavalleru, Andhra Pradesh, India.
Received: September 22, 2020

Published: October 08, 2020

(C) All rights are reserved by Veenam Bhavya Naga Vani., et al.

\section{Abstract}

The Mansoa alliaceae leaves contain many medical applications. The plant leaves contain anti-inflammatory activity, anti-oxidant activity, anti-arthritic activity, anti-rheumatic activity, anti-septic activity, anti-fungal activity and anti-bacterial activity. The present study was aimed to determine the anti-bacterial activity of ethanolic extract of Mansoa alliaceae leaves.

Keywords: Anti-Bacterial Activity; Mansoa alliaceae; Anti-Oxidant Activity

\section{Introduction}

According to world health organization, many of people use medicinal plants to treat their diseases. In olden days Mansoa alliaceae leaves used to treat many of the diseases in European countries. Mansoa alliaceae plant contains many medical uses like bacterial activity, fungicidal activity, arthritic activity, inflammatory activities. In the phytochemical studies the leaves contains flavonoids, alkaloids, glycosides, carbohydrates etc.

\section{Materials and Methods}

\section{Materials}

Collection, authentication and treatment of plant material

The leaves of plant Mansoa alliaceae belonging to the family bignoniaceae to were collected from surroundings of Tirupathi, Andhra Pradesh, India in the month of June. The plant material was authenticated.

\section{Extraction}

1. The leaves of Mansoa alliaceae were shade dried for 7 days. The leaves were weighed about 100 gm and subjected for extraction with ethanol by soxhlet apparatus for $72 \mathrm{hrs}$.
2. Concentrate each extract by distillating off the solvent and then evaporating to dryness on the water-bath.

3. Weigh the extract obtained and calculate its percentage in terms of the air-dried weight of the plant material. Also note the consistency of the extract.

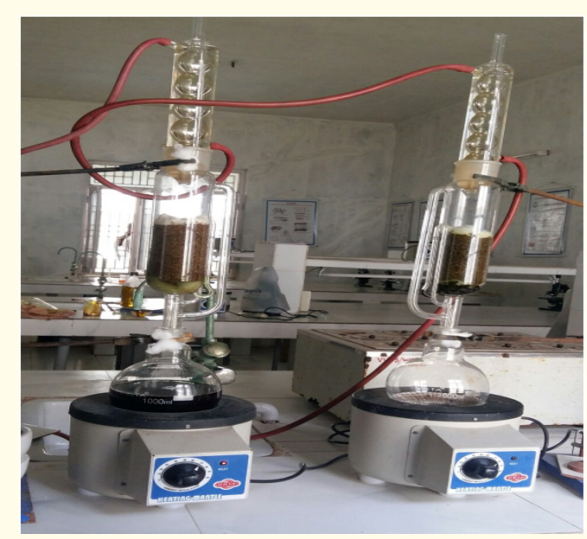

Figure 1: Extraction by soxhlet apparatus. 


\section{Preliminary phytochemical screening}

Preliminary phytochemical screening was carried out by using standard procedure. The ethanolic extract of Mansoa alliaceae was tested for the presence of phytoconstituents viz. carbohydrates, proteins, alkaloids, flavonoids, saponins and glycosides.

\section{Test for carbohydrates}

- Molisch test: To $1 \mathrm{mg}$ powder, two drops of alcoholic solution of alpha naphthol were added. The mixture was shaken and $1 \mathrm{ml}$ of concentrate sulphuric acid was added slowly along the sides of the test-tube, the test tube was cooled in ice water and allowed to stand. A violet coloured ring at the junction indicates the presence of carbohydrates.

- Benedicts test: To $1 \mathrm{mg}$ of powdered drug $0.5 \mathrm{ml}$ of benedicts reagent was added. The mixture was heated on boiling water bath for 2 minutes. A red green or yellow colored precipitate indicates the presence of sugar.

\section{Test for alkaloids}

- Dragendroff's test: To the $2 \mathrm{ml}$ of test solution add $2 \mathrm{ml}$ of Dragendroff's reagent (Potassium bismuth iodide solution) Reddish brown precipitate indicates the presence of alkaloids.

\section{Test for flavonoids}

- Shinoda test: To the test solution add few magnesium turnings and concentrated hydrochloric acid drop wise, pink scarlet crimson red are occasionally green to blue color appears after few minutes.

\section{Test for saponins}

- $\quad$ Froth formation test: Place $2 \mathrm{ml}$ solution of drug in water in a test tube, shake well, stable froth foam is formed.

\section{Test for glycosides}

Borntragers test: Boil the test material with $1 \mathrm{ml}$ of sulphuric acid in a test tube for 5 minutes and filter while hot. Cool the filtrate and shake with equal volume of chloroform. Separate the lower layer of chloroform and shake it with half of its volume of dilute ammonia. A rose pink to red color is produced in the ammonical layer.

\section{Test for terpenoids}

Liebermann-Burchard test: 2 - $3 \mathrm{ml}$ of extract, 2 - 3 drops of dry chloroform was added and several drops of acetic anhydride solution followed by $2 \mathrm{ml}$ of glacial acetic acid were added. The above solution was made warmed and cooled. 2 - 3 drops of conc. $\mathrm{H}_{2} \mathrm{SO}_{4}$ was added along with the sides of the test tube.

\section{Test for fats and oils}

- $\quad$ Spot test: An extract drop was placed on filter paper and the stain was observed.

- Saponification test: To small quantity of each extract $0.5 \mathrm{~N}$ alcoholic potassium hydroxide was added along with a drop of phenolphthalein and heated on water bath for 2 hours. Formation of soap takes place.

Test for gums and mucilage

- Diluted extract was added to the test tube containing alcohol with continuous stirring results in precipitation.

- $\quad$ Extract treated with Ruthenium red results, red color.

\section{Test for resins}

To 5 - $10 \mathrm{ml}$ of extract acetic anhydride was added, heated followed by cooling. After cooling $0.5 \mathrm{ml}_{\text {of }} \mathrm{H}_{2} \mathrm{SO}_{4}$ was added results in bright purplish red changes to violet color rapidly.

\section{Evaluation of anti-bacterial activity}

\section{Bacterial strains}

The antibacterial potency of leaves of Mansoa alliaceae was evaluated using four bacterial strains viz., two strains of Gram negative Escherichia coli, Pseudomonas aeruginosa, two strains of Gram positive Staphylococcus aureus and Bacillus subtilis.

\section{Inoculums preparation}

Each bacterial strain was sub cultured overnight at $35^{\circ} \mathrm{C}$ in Mueller-Hilton agar slants. The bacterial growth was harvested using $5 \mathrm{ml}$ of sterile saline water and diluted to attain viable cell count of $10^{7} \mathrm{CFU} / \mathrm{ml}$.

\section{Determination of minimum inhibitory concentrations (MIC's) of the effective plant extract}

MIC is defined as the lowest concentration of the antimicrobial agent that inhibits the microbial growth after $24 \mathrm{~h}$ of incubation. The most effective plant extracts which exhibiting a strong antibacterial activity at $10 \mathrm{mg} / \mathrm{ml}$ was manipulated to determine their MIC using cup plate method and evaluate their efficiency in controlling bacterial strains. Different concentrations of the effective plant extract $(1.25,2.5,5.0,10.0,12.5$ and $15.0 \mathrm{mg} / \mathrm{ml})$ were prepared separately by dissolving $50 \mathrm{mg}$ in DMSO (Dimethyl sulfoxide), sterilized through Millipore filter and loaded in cups. Nutrient 
Agar was poured into sterile Petri dishes and seeded with bacterial suspensions of the strains. The plates were kept in the fridge at $5^{\circ} \mathrm{C}$ for $2 \mathrm{~h}$. then incubated at $35^{\circ} \mathrm{C}$ for $24 \mathrm{~h}$. The inhibition zones were measured by Vernier caliper and recorded against the concentrations of the effective plant extracts.

Antibacterial activity of Ethanolic leaves extract of Mansoa alliaceae

The Cup plate method is used to evaluate antimicrobial activity of the each plant extract. The plant extract residues $(50 \mathrm{mg}$ ) were re-dissolved in DMSO (Dimethyl sulfoxide), sterilized through Millipore filter $(0.22 \mu \mathrm{m})$ then loaded in cups prepared by sterile cork borer to obtain final concentration of $10 \mathrm{mg} /$ disc. Ten $\mathrm{ml}$ of agar medium was poured into sterile Petri dishes (as a basal layer) followed with $15 \mathrm{ml}$ of seeded medium previously inoculated with bacterial suspension ( $100 \mathrm{ml}$ of medium $/ 1 \mathrm{ml}$ of $10^{7} \mathrm{CFU}$ ) to attain $10^{5} \mathrm{CFU} / \mathrm{ml}$ of medium. The cups were loaded with plant extract concentration of 10, 20, 40 and $60 \mathrm{mg} / \mathrm{ml}$ were placed on the top of Nutrient Agar plates. The cups loaded with $5 \mu \mathrm{g}$ of Amoxycillin was used as positive control. The plates were kept in the fridge at $5^{\circ} \mathrm{C}$ for $2 \mathrm{~h}$ to permit plant extracts diffusion then incubated at $35^{\circ} \mathrm{C}$ for $24 \mathrm{~h}$. The presence of inhibition zones were measured by Vernier calliper, recorded and considered as indication for antibacterial activity.

\section{Results}

Extraction: The leaves of Mansoa alliaceae were subjected for drying for a period of 7 days. After drying the powder is made extracted with the solvent ethanol and the extract obtained is subjected for the preliminary phytochemical screening.

\section{Preliminary phytochemical screening}

Preliminary phytochemical analysis revealed the presence of phytoconstituents carbohydrates, proteins, alkaloids, flavonoids, saponins and glycosides (Table 1).

\begin{tabular}{|c|c|c|}
\hline S. No. & Test & $\begin{array}{c}\text { Ethanolic leaf extract of Mansoa } \\
\text { alliaceae }\end{array}$ \\
\hline 1 & Carbohydrates & + \\
\hline 2 & Protein & + \\
\hline 3 & Alkaloids & + \\
\hline 4 & Flavonoids & + \\
\hline 5 & Saponins & - \\
\hline 6 & Glycosides & + \\
\hline
\end{tabular}

Table 1: Preliminary phytochemical screening for Mansoa alliaceae.

$+:$ : Presence, $-:$ :Absence.

\section{Evaluation of antibacterial activity}

\begin{tabular}{|c|c|c|c|c|c|c|c|c|c|c|}
\hline \multirow{3}{*}{$\begin{array}{c}\text { S. } \\
\text { No. }\end{array}$} & \multirow{3}{*}{ Extract } & \multirow{3}{*}{ Strain } & \multicolumn{8}{|c|}{ Zone of inhibition (mm) } \\
\hline & & & \multicolumn{8}{|c|}{ Concentration $(\mu \mathrm{g} / \mathrm{ml})$} \\
\hline & & & $\begin{array}{c}\text { Standard (5 } \\
\mu \mathrm{g} / \mathrm{ml})\end{array}$ & $\begin{array}{l}\text { Con- } \\
\text { trol }\end{array}$ & 1 & 10 & 20 & 30 & 40 & 50 \\
\hline \multirow[t]{4}{*}{1.} & \multirow{4}{*}{$\begin{array}{l}\text { Ethano- } \\
\text { lic leaf } \\
\text { extract of } \\
\text { Mansoa } \\
\text { alliaceae }\end{array}$} & E. coli & $18 \pm 0.1 \mathrm{~mm}$ & 0 & $\begin{array}{l}\text { No } \\
\text { Zone }\end{array}$ & $\begin{array}{c}5.0 \pm 0.2 \\
\mathrm{~mm}\end{array}$ & $\begin{array}{c}8.0 \pm 0.1 \\
\mathrm{~mm}\end{array}$ & $\begin{array}{c}12.0 \pm 0.2 \\
\mathrm{~mm}\end{array}$ & $\begin{array}{c}15.0 \pm 0.1 \\
\mathrm{~mm}\end{array}$ & $\begin{array}{c}17.0 \pm 0.2 \\
\mathrm{~mm}\end{array}$ \\
\hline & & $\begin{array}{l}\text { P. aerugi- } \\
\text { nosa }\end{array}$ & $19 \pm 0.2 \mathrm{~mm}$ & 0 & $\begin{array}{l}\text { No } \\
\text { Zone }\end{array}$ & $\begin{array}{c}4.0 \pm 0.1 \\
\mathrm{~mm}\end{array}$ & $\begin{array}{c}6.0 \pm 0.2 \\
\mathrm{~mm}\end{array}$ & $8.0 \pm 0.1 \mathrm{~mm}$ & $\begin{array}{c}9.0 \pm 0.2 \\
\mathrm{~mm}\end{array}$ & $\begin{array}{c}12.0 \pm 0.1 \\
\mathrm{~mm}\end{array}$ \\
\hline & & S. aureus & $17 \pm 0.1 \mathrm{~mm}$ & 0 & $\begin{array}{l}\text { No } \\
\text { Zone }\end{array}$ & $\begin{array}{c}5.0 \pm 0.2 \\
\mathrm{~mm}\end{array}$ & $\begin{array}{c}9.0 \pm 0.1 \\
\mathrm{~mm}\end{array}$ & $\begin{array}{c}13.0 \pm 0.2 \\
\mathrm{~mm}\end{array}$ & $\begin{array}{c}14.0 \pm 0.1 \\
\mathrm{~mm}\end{array}$ & $\begin{array}{c}15.0 \pm 0.2 \\
\mathrm{~mm}\end{array}$ \\
\hline & & B. subtilis & $16 \pm 0.2 \mathrm{~mm}$ & 0 & $\begin{array}{l}\text { No } \\
\text { Zone }\end{array}$ & $\begin{array}{c}6.0 \pm 0.1 \\
\mathrm{~mm}\end{array}$ & $\begin{array}{c}8.0 \pm 0.2 \\
\mathrm{~mm}\end{array}$ & $\begin{array}{c}11.0 \pm 0.1 \\
\mathrm{~mm}\end{array}$ & $\begin{array}{c}13.0 \pm 0.2 \\
\mathrm{~mm}\end{array}$ & $\begin{array}{c}14.0 \pm 0.1 \\
\mathrm{~mm}\end{array}$ \\
\hline
\end{tabular}

Table 2: Zone of inhibition of ethanolic extract of Mansoa alliaceae against selected both gram negative and gram positive bacteria.

Zone of inhibition of different extracts

Ethanolic leaf extract of Mansoa alliaceae on the strain E. coli

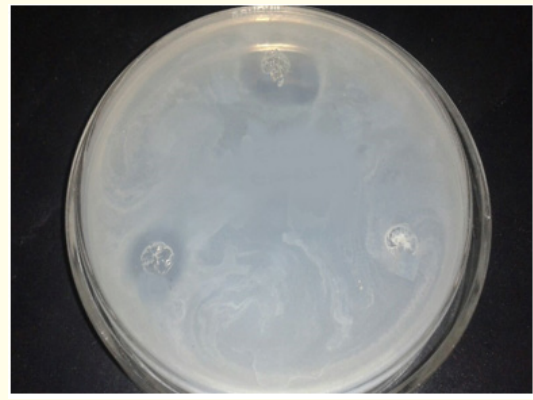

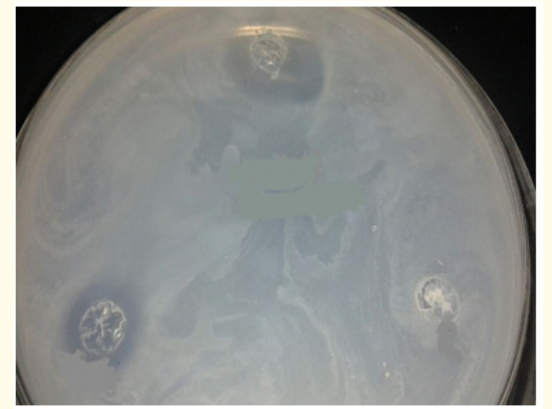

Figure 3

Figure 2

Citation: Veenam Bhavya Naga Vani., et al. "Evaluation of Anti-Bacterial Activity of Mansoa alliaceae Leaves". Acta Scientific Pharmaceutical Sciences 4.11 (2020): 07-13. 


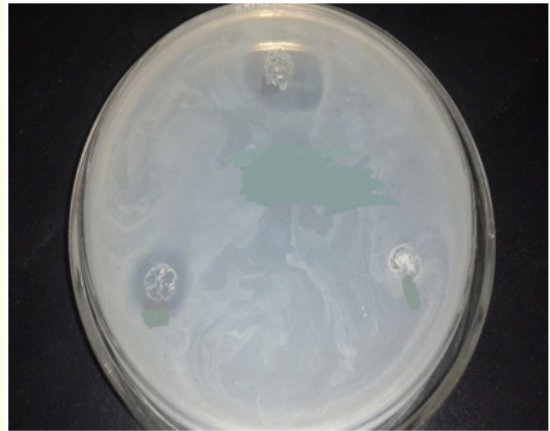

Figure 4

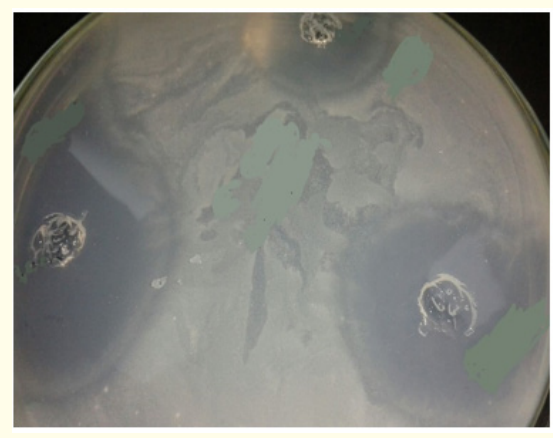

Figure 5

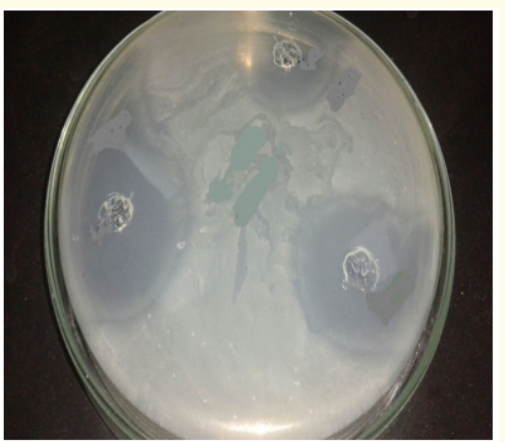

Figure 6

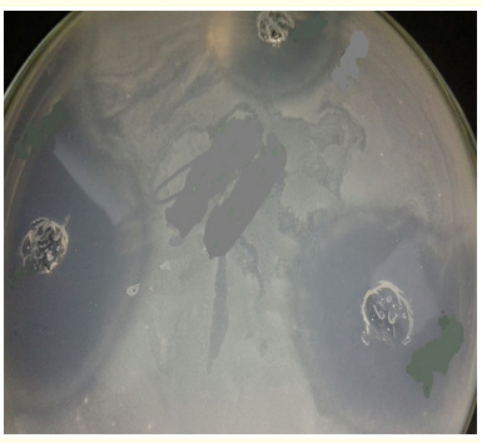

Figure 7

\section{Zone of inhibition of different extracts}

Ethanolic leaf extract of Mansoa alliaceae on the strain P. aeruginosa

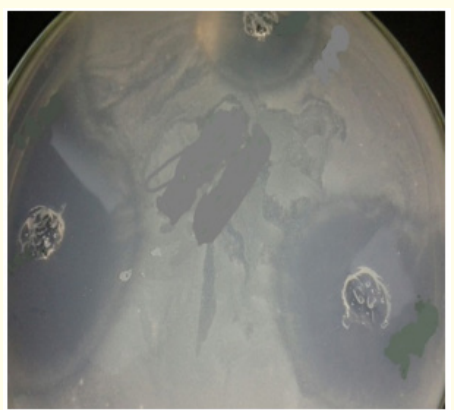

Figure 8

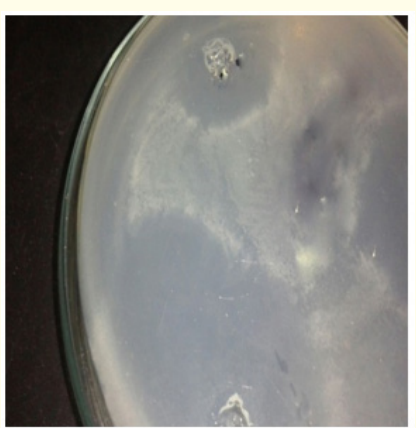

Figure 9

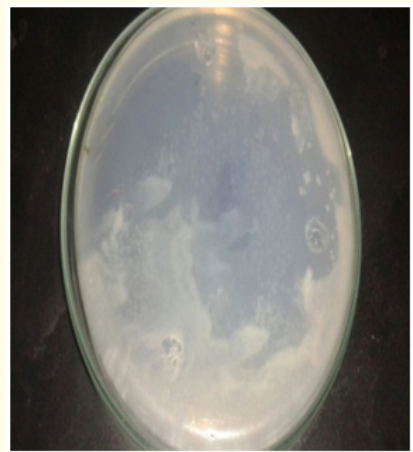

Figure 10

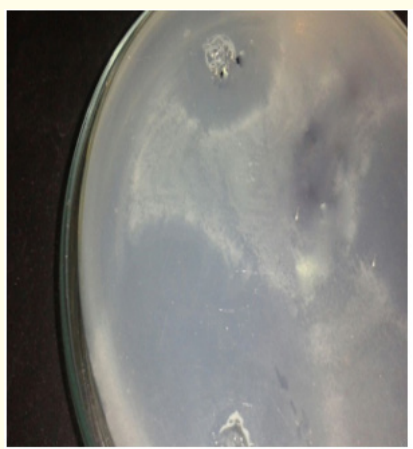

Figure 11 


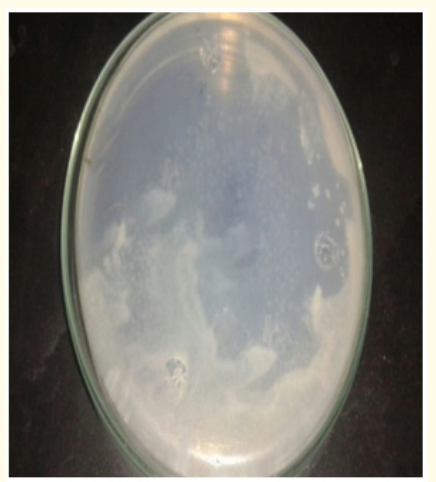

Figure 12

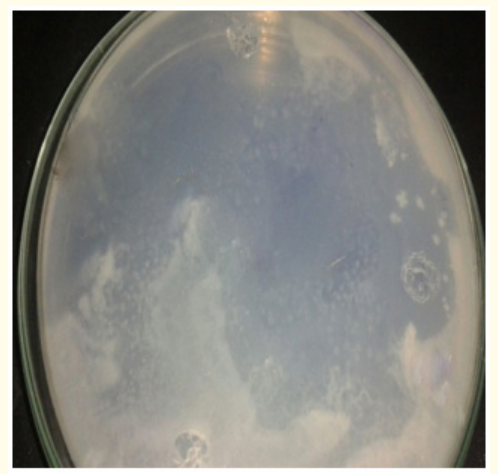

Figure 13

\section{Zone of inhibition of different extracts}

Ethanolic leaf extract of Mansoa alliaceae on the strain $S$, aureus
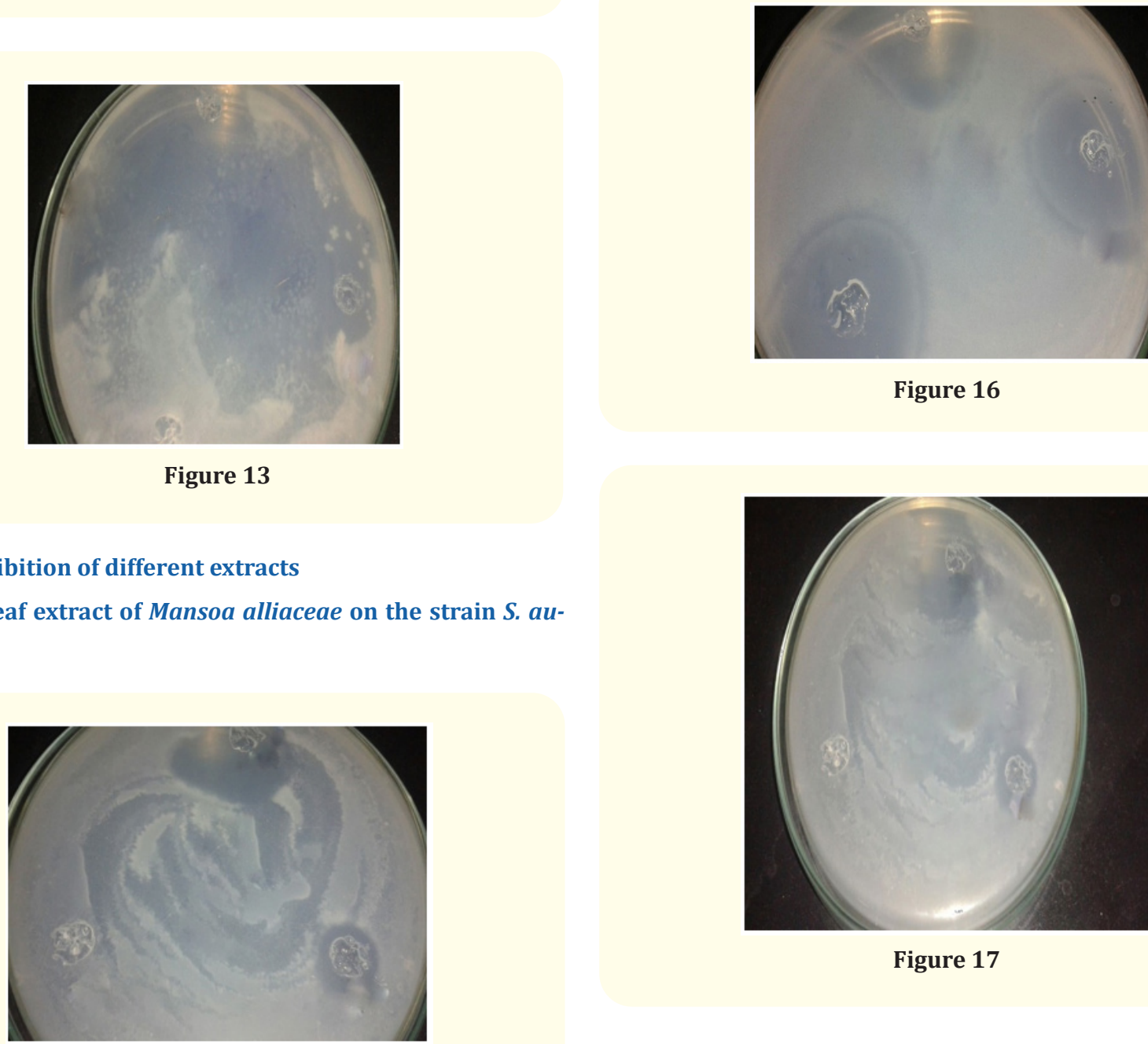

Figure 16

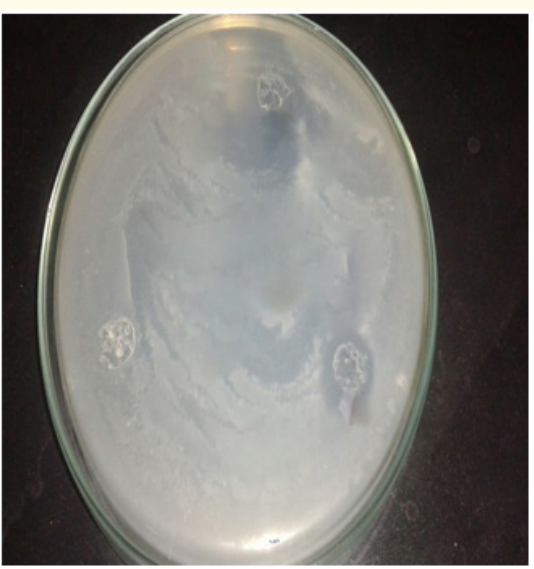

Figure 17

Figure 14 


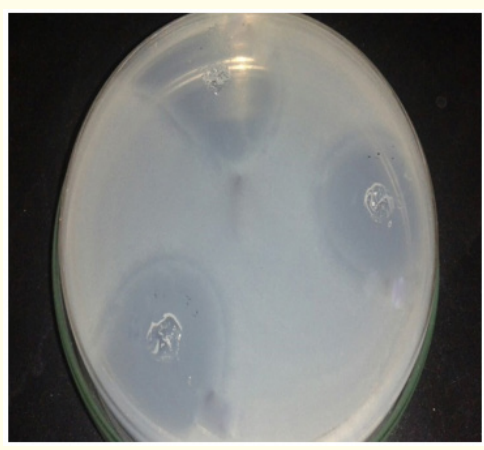

Figure 18

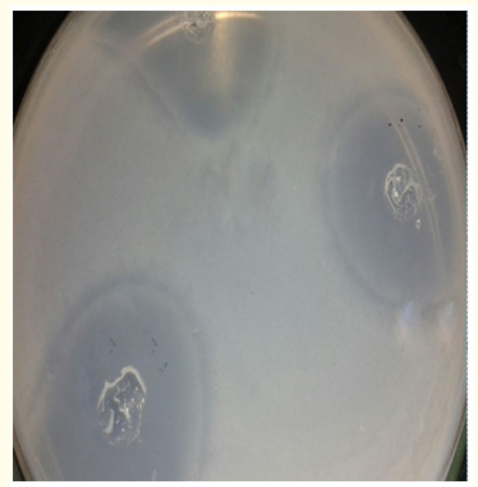

Figure 19

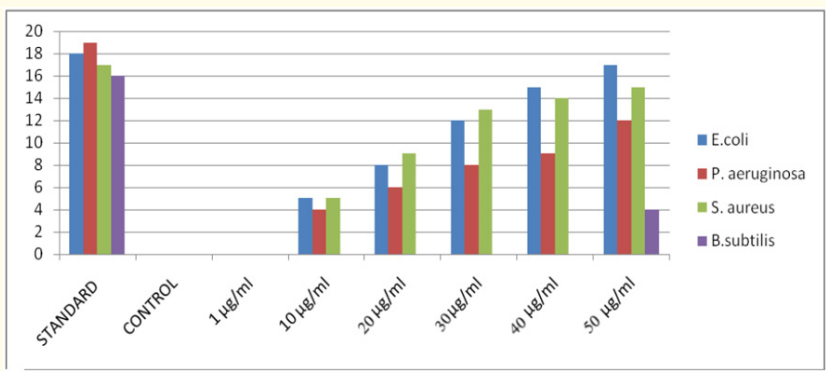

Graph 1: Zone of inhibition of ethanolic extract of Mansoa alliaceae.

\begin{tabular}{|c|c|c|}
\hline Extract & Name of the Organism & $\begin{array}{l}\text { Results } \\
\text { Obtained }\end{array}$ \\
\hline \multirow{4}{*}{$\begin{array}{l}\text { Ethanolic Extract of } \\
\text { Decaschistia crotonifolia }\end{array}$} & Escherichia coli & +ve \\
\hline & Staphylococcus aureus & +ve \\
\hline & $\begin{array}{l}\text { Pseudomonas aerugi- } \\
\text { nosa }\end{array}$ & +ve \\
\hline & Bacillus subtilis & +ve \\
\hline
\end{tabular}

Table 3: Antibacterial activity of leaf extract of Mansoa alliaceae against gram negative and gram positive bacteria.

\section{Discussion}

The antimicrobial study of ethanolic leaf extract of Mansoa alliaceae revealed that the ethanolic extract shown the antimicrobial activity against $E$. coli, $S$. aureus and $P$. aeruginosa and B. subtilis in concentrations of $10,20,30,40$ and $50 \mu \mathrm{g} / \mathrm{ml}$ but it shown very slight antimicrobial activity against $B$. subtilis in the concentration of $50 \mu \mathrm{g} / \mathrm{ml}$ [1-15].

\section{Conclusion}

Multiple drug resistance has developed due to the indiscriminate use of commercial antimicrobial drugs commonly used in the treatment of infectious diseases. In addition to this problem, antibiotics are sometimes associated with adverse effects. This situation force scientists to search for new antimicrobial substances. Given the alarming incidence of antibiotic resistance in bacteria of medical importance, there is a constant need for new and effective therapeutic agents. Plant based antimicrobials represent a vast untapped source of medicines and further exploration of plant antimicrobials need to occur. Antimicrobials of plant origin have enormous therapeutic potential. They are effective in the treatment of infectious diseases while simultaneously mitigating many of side effects that are often associated with synthetic antimicrobials.

The antibacterial study of ethanolic leaf extract of Mansoa alliaceae revealed that it shown the antibacterial activity against $E$. coli, $S$. aureus, $P$. aeruginosa and $B$. subtilis.

\section{Acknowledgement}

Authors are sincerely thankful to V.V institute of pharmaceutical sciences, Gudlavaalleru for providing necessary facilities for carry out research work.

\section{Bibliography}

1. MS Baliga., et al. "Ginger (Zingiber officinale Roscoe) in the treatment and prevention of arthritis". Bioactive Food as Dietary Interventions for Arthritis and Related Inflammatory Diseases (2013): 529-544.

2. Ananthanarayan and Paniker's. "Text book of Microbiology". $8^{\text {th }}$ edition. University press private limited., India (2009): 3.

3. KA Raveesha. "Phytochemical investigations of Antibacterial of Some Medicinal Plants". Journal of Applied Pharmaceutical Science (2011): 3.

4. B Jaya lakshmi., et al. "Antibacterterial Evaluation of Plant Extracts Against Some Human Pathogenic". IDOSA Publications (2008): 43.

5. Panthati Murali Krishna., et al. "Pharmacognostical studies and preliminary phytochemical investigations on roots of Sophora interrupta Bedd (2011): 57. 
6. Kokate CK., et al. "Text book of Pharmacognosy". $45^{\text {th }}$ edition, Nirali Publications, India (2010): 22-24.

7. Trease and Evans. "Text book of Pharmacognosy". 16 ${ }^{\text {th }}$ edition, Saunders Publications (2013): 136-137.

8. Kokate CK. "Practical Pharmacognosy". Vallabh Prakashan., New Delhi (1986): 111.

9. Har bone JB. "Method of extraction and isolation in phytochemical methods". Champman and Hill., London (1998): 6066.

10. Vinod D Rangari. "Pharmacognosy and Phytochemistry Volume I". Career Publications, India (2009): 95-97.

11. Varun kumar Malhothra. "Handbook of Practical biochemistry". Jaypee Brothers Medical Publishers., New Delhi (2009): 7-14.

12. Singh SP. "Concept of Biochemistry for Physiotherapy and Pharmacy". CBS Publishers and Distributors, New Delhi (2007): 21.

13. TE Wallis. "Text Book of Pharmacognosy, $5^{\text {th }}$ edition". CBS Publication., India (2004): 579.

14. Salwa M Abdel Rahman., et al. "Antibacterial activity of some wild medicinal plants collected from Natural alternatives for infectious disease treatment". African Journal of Biotechnology 10.52 (2011): 10733-10743.

15. Sato M., et al. "Antibacterial activity of flavanone isolated form Sophora exigua against methicillin resistant Staphylococcus aureus and its combination with antibiotics". Phytotherapy Research (1995): 95-97.

\section{Assets from publication with us}

- Prompt Acknowledgement after receiving the article

- Thorough Double blinded peer review

- Rapid Publication

- Issue of Publication Certificate

- High visibility of your Published work

Website: www.actascientific.com/

Submit Article: www.actascientific.com/submission.php

Email us: editor@actascientific.com

Contact us: +919182824667

Citation: Veenam Bhavya Naga Vani., et al. "Evaluation of Anti-Bacterial Activity of Mansoa alliaceae Leaves". Acta Scientific Pharmaceutical Sciences 4.11 (2020): 07-13. 